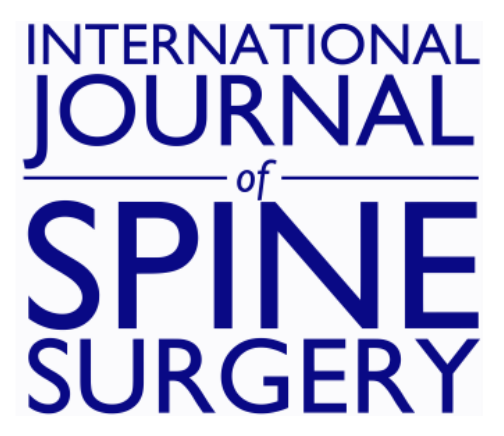

\title{
Editors' Introduction: Modern Technology Applications in Minimally Invasive Spine Surgery Techniques
}

Kai-Uwe Lewandrowski, Domagoj Coric, Anthony Yeung and Michael Y. Wang

Int J Spine Surg 2020, 14 (s3) S3

doi: https://doi.org/10.14444/7120

http://ijssurgery.com/content/14/s3/S3

This information is current as of April 26, 2023.

Email Alerts Receive free email-alerts when new articles cite this article. Sign up at:

http://ijssurgery.com/alerts 


\title{
Editors' Introduction: Modern Technology Applications in Minimally Invasive Spine Surgery Techniques
}

\author{
KAI-UWE LEWANDROWSKI, MD, ${ }^{1}$ DOMAGOJ CORIC, MD ${ }^{2,3}$ ANTHONY YEUNG, MD ${ }^{4}$ MICHAEL Y. \\ WANG, MD \\ ${ }^{1}$ Center for Advanced Spine Care of Southern Arizona, Tucson, Arizona,${ }^{2}$ Carolina Neurosurgery \& Spine Associates, Charlotte, North Carolina,${ }^{3}$ Atrium \\ Musculoskeletal Institute, Charlotte, North Carolina, ${ }^{4}$ University of New Mexico School of Medicine Department of Neurosurgery Albuquerque, New Mexico, \\ Desert Institute for Spine Care, Phoenix, Arizona, ${ }^{5}$ Department of Neurosurgery \& Rehabilitation Medicine, University of Miami Miller School of Medicine, \\ Miami, Florida
}

As a matter of tradition, the International Journal of Spine Surgery (IJSS) is proud to bring to you yet another special issue, this time highlighting some of the contemporary modern technology applications in minimally invasive spinal surgery and how those applications impact patient outcomes. Examples include endoscopic spinal surgery, expandable cage, non-fusion technologies, artificial intelligence, and novel combinations and staged application of existing technologies in ways that are available to readers for the first time.

We, the editors of this IJSS special issue, have attempted to provide a timely and exciting collage of original articles that we are confident readers will find both timely and highly informative. The selection of articles was based on the demand for clinical studies that reflect contemporary trends in minimally invasive and endoscopic spinal surgery, which in many countries is increasingly accepted and adopted. We recognize that this trend results from the need for less costly, yet safe and efficient solutions for the spine's common degenerative conditions. Patients and other stakeholders in the ongoing debate on better valuebased spine care, including healthcare policymakers and payers, are demanding that spine surgeons improve on the complication, reoperation, and readmission rates established and accepted with open spinal surgeries. Patients are looking for less burdensome and risky treatments with shorter time to recovery, return to work, and social reintegration following spine surgery.

This IJSS special issue also attempts to provide readers with a snapshot of contemporary diagnostic algorithms and procedures intended to treat the spine's common conditions with the use of advanced instrumentation and technologies targeted at vali- dated pain generators. Furthermore, it provides the reader with a synopsis of the fundamentals of endoscopic and other minimally invasive spine surgery techniques by discussing the historical background, clinically relevant aspects of applied physics and computer science, choice of anesthesia, indications, appropriate patient selection, and expected clinical outcomes. We hope that this IJSS special issue will motivate readers to become more interested than ever in modern minimally invasive and endoscopic spinal surgery.

Disclosures and COI: K.L.: None. D.C.: Medtronic (consultant, royalties); Spine Wave (consultant, royalties, direct stock ownership). A.Y.: Bonovo (consulting, investment); Elliquence (consultant, royalties); Micron (consulting, investment); Richard Wolf (consultant, royalties). M.Y.W.: Depuy-Synthes Spine (consultant); Globus (speakers' bureau); Medtronic (speakers' bureau); Innovative Surgical Devices (stock); Medical Device Partners (stock); Spineology (consultant); Stryker (consultant).

Corresponding Author: Kai-Uwe Lewandrowski, MD, Staff Orthopaedic Spine Surgeon, Center for Advanced Spine Care of Southern, Arizona and Surgical Institute of Tucson, AZ 85712. Phone: (520) 204-1495; Fax: (623) 2181215; Email: busniess@tucsonspine.com.

Published 9 December 2020

This manuscript is generously published free of charge by ISASS, the International Society for the Advancement of Spine Surgery. Copyright (C) 2020 ISASS. To see more or order reprints or permissions, see http://ijssurgery.com. 